\title{
Modulation of production of matrix metalloproteinases from ovine endometrial cells by ovine trophoblast interferon
}

\author{
L. A. Salamonsen ${ }^{1}$, A. L. Hampton ${ }^{1}$, R. Suzuki ${ }^{2}$ and H. Nagase ${ }^{2}$ \\ ${ }^{1}$ Prince Henry's Institute of Medical Research, PO Box 152, Clayton, Victoria 3168, Australia; and \\ ${ }^{2}$ Department of Biochemistry and Molecular Biology, University of Kansas Medical Center, \\ Kansas City, KS 66103, USA
}

\begin{abstract}
Ovine trophoblast interferon modulates the secretion of a number of proteins by ovine endometrium, but only one of these proteins has so far been identified. We examined the effects of trophoblast interferon on the secretion of matrix metalloproteinase- $1,-2$ and -3 by cultured ovine endometrial cells and determined whether they are mediated via effects on prostaglandin synthesis. Both ovine trophoblast interferon $\left(30 \mathrm{ng} \mathrm{ml}{ }^{-1}\right.$ ) and human recombinant interferon $\alpha\left(50 \mathrm{U} \mathrm{ml}^{-1}\right)$ inhibited the production of latent matrix metalloproteinase- 1 and $-3(P<0.05)$, as measured by enzyme assays, but had no effect on the secretion of latent matrix metalloproteinase-2. These inhibitory effects were not overcome by $\mathrm{PGE}_{2}$ or $\mathrm{PGF}_{2 \alpha}$ (each $10 \mu \mathrm{mol} \mathrm{\textrm {I } ^ { - 1 }}$ ) either alone or in combination. Indomethacin $\left(12 \mu \mathrm{mol} \mathrm{l}^{-1}\right)$ similarly inhibited the production of latent matrix metalloproteinase- $I$ and -3 , but production was partially restored by adding the prostaglandins either singly or in combination. $\mathrm{PGE}_{2}$ and $\mathrm{PGF}_{2 \alpha}$ together had no effect on enzyme production. These data were confirmed by gelatin and casein zymography. Northern analysis showed a 4.5 -fold increase in the abundance of specific mRNA for latent matrix metalloproteinase- $I$ following treatment of cells with phorbol myristate acetate, but a marked decrease following interferon treatment. Thus, ovine trophoblast interferon inhibits the production of the latent forms of matrix metalloproteinase- 1 and -3 by ovine endometrial cells, and this is independent of its effect on prostaglandin production.
\end{abstract}

\section{Introduction}

The sheep trophoblast secretes a number of proteins into the uterine lumen (Godkin et al., 1982; Salamonsen et al., 1984) while undergoing extensive elongation during the periimplantation period (12-16 days after ovulation; Bindon, 1971). The dominant secreted protein is a $19 \mathrm{kDa}$ protein (Godkin et al., 1982), now identified as a type I interferon (Imakawa et al., 1987; Stewart et al., 1987; Charpigny et al., 1988), for which, along with other ruminant trophoblast interferons, a nomenclature of IFN $\tau$ has recently been suggested (Roberts et al., 1992). It has profound paracrine effects on the endometrium, attenuating the production of uterine prostaglandins (PG; Salamonsen et al., 1988; Vallet et al., 1988) and particularly of $\mathrm{PGF}_{2 \alpha^{\prime}}$ which in the sheep is the luteolytic agent, but also the production of PGE (Salamonsen et al., 1988, 1989). Furthermore it modifies the pattern of protein secretion by both endometrial explants and cultured endometrial cells in vitro (Godkin et al., 1984; Salamonsen et al., 1988; Sharif et al., 1989). However, only one of these interferon-responsive proteins has been identified (Vallet et al., 1991). The actions of IFN $\tau$ in vitro can be mimicked by recombinant human or bovine IFNa (Salamonsen et al., 1988,

Received 18 February 1994.
1989; Francis et al., 1991), which share common IFNa/ $\beta$ receptors. These are present in the ovine endometrium (Stewart et al., 1987; Hansen et al., 1989; Knickerbocker and Niswender, 1989; Russell et al., 1993) in greater numbers than on any other ovine tissue tested (corpus luteum, spleen, adrenal cortex, kidney, skeletal muscle, cerebral cortex; Knickerbocker and Niswender, 1989) or on bovine spleen or human placenta and endometrium (Russell et al., 1993).

In the sheep and other ungulates that have similar epitheliochorial placentation, early stages of implantation involve the fusion of binucleate cells of trophoblast origin with caruncular epithelial cells, and some penetration of the basal lamina occurs at defined sites near areas of formation of minisyncytia (Wooding and Morgan, 1989). However, little is known of events in the endometrial stroma at this time, although reorganization of the vasculature and associated structural changes in the interstitial matrix would be required in association with a greatly enhanced blood supply to the implantation site (Weitlauf, 1988).

Sheep endometrial cells in primary culture secrete a number of matrix metalloproteinases (MMPs): interstitial collagenase (MMP-1), gelatinase A (MMP-2) and stromelysin 1 (MMP-3) (Salamonsen et al., 1991b, 1993). Our previous studies have demonstrated the presence of matrix metalloproteinases in uterine flushings from pregnant ewes on day 16 of gestation 
and in medium following the culture of conceptuses isolated on day 16 (Salamonsen $e t$ al., in press). This family of enzymes together have the potential to degrade most components of the extracellular matrix and are therefore likely to play an important role in the tissue remodelling associated with implantation. Regulation of MMP activity can occur at a number of levels: gene transcription; activation of latent enzyme; or inactivation of the active enzyme by its binding to specific tissue inhibitors of MMPs (Woessner, 1991; Birkedal-Hansen et al., 1993). A wide range of regulatory molecules can act as either inducers (Brenner et al., 1989; Auble and Brinkerhoff, 1991) or inhibitors (Jonat et al., 1990; Yang-Yen et al., 1990) of MMP production. Bioregulators of MMP genes include cytokines, growth factors, prostaglandins and steroid hormones, their actions varying with cell type. It seems likely that at the time of implantation, IFN $\tau$, the dominant product of the trophoblast cells, could be an important regulator of MMP production either directly or via its known actions on prostaglandin activity.

The aim of the present study was to examine the effects of IFN $\tau$ and human recombinant interferon $\alpha$ (IFN $\alpha$ ) on the production of proMMP-1, proMMP-2 and proMMP-3 by ovine endometrial cells in culture, and to establish whether any changes observed were mediated via the known actions of the interferons on prostaglandin synthesis.

\section{Materials and Methods}

\section{Animals}

Ten parous Corriedale ewes were ovariectomized and maintained for at least $I$ month before treating them with implants of oestradiol (days 1-12) plus intravaginal inserts containing progesterone (CIDR-G: Riverina Artificial Breeders Pty Ltd, Albury) from day 3 to day 12 to mimic the oestrous cycle (Salamonsen et al., 1991b). On day 12 the ewes were initially anaesthetized i.v. with a mixture of $6 \mathrm{ml} 10 \%$ sodium pentobarbitone (May and Baker, Melbourne) and $3 \mathrm{ml}$ Nembutal $\left(60 \mathrm{mg} \mathrm{ml}{ }^{-1}\right.$; Bomac Laboratories, Asquith), maintained on halothane/oxygen and then hysterectomized. The endometrium was dissected from the myometrium.

\section{Cell isolation and culture}

A mixture of stromal fibroblasts and epithelial cells was prepared from the endometrium using techniques described by Salamonsen et al. (1991b). In brief, tissue was chopped finely with scissors, digested with $150 \mathrm{U}$ bacterial collagenase $\mathrm{ml}^{-1}$ (type 111; Worthington Biochemical Corporation, Freehold, $\mathrm{NJ}$ ), incubated in a shaking water bath at $37^{\circ} \mathrm{C}$ for $75 \mathrm{~min}$ and filtered through two grades of nylon mesh. The cell mixture was centrifuged ( $200 \mathrm{~g}$ for $5 \mathrm{~min}$ ) at room temperature through a Ficoll gradient (2-20\%; Pharmacia Ltd, Uppsala) and the cells lying at the interfaces $6-8 \%, 8-10 \%$ and $10-20 \%$ were pooled and counted. Cells $\left(2 \times 10^{6}\right.$ per well) were plated into 24 -well culture dishes in $2 \mathrm{ml}$ medium 199 with $10 \%$ fetal calf serum and $100 \mathrm{U}$ penicillin/100 $\mathrm{U}$ streptomycin/250 ng fungisone $\mathrm{ml}^{-1}$ (PSF; all from Flow Laboratories, Sydney), and left for $24-48 \mathrm{~h}$ until nearly confluent. They were then washed three times with PBS and the medium was replaced with $1 \mathrm{ml}$ medium 199 containing antibiotics only. Treatments were added into triplicate wells as $10 \mu \mathrm{I}$ aliquots of $100 \times$ solutions and included $12 \mu \mathrm{g}$ indomethacin $\mathrm{ml}^{-1}, 40 \mathrm{nmol}$ phorbol myristate acetate (PMA) $1^{-1}, 10 \mu \mathrm{mol} \mathrm{PGE} \mathrm{I}^{-1}$ and $10 \mu \mathrm{mol}$ $\mathrm{PGF}_{2 \alpha} \mathrm{l}^{-1}$ (all from Sigma Chemical Co., St Louis, MO). These concentrations of prostaglandins represent the upper range secreted from similar cultures in $48 \mathrm{~h}$ (Salamonsen et al., 1989).

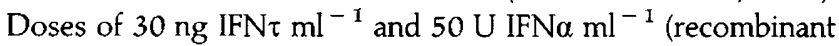
human $\alpha_{2}$ a; Hoffman La Roche \& Co., Basel) maximally modulate prostaglandin and protein synthesis by similar cell cultures, and do not affect the proliferation of such cultures (Salamonsen et al., 1989). Cultures were maintained for a further $48 \mathrm{~h}$, and the medium was collected, centrifuged $(200 \mathrm{~g}$ for $5 \mathrm{~min}$ at room temperature) and stored at $-20^{\circ} \mathrm{C}$ until analysis. Each experiment was performed separately in cell cultures from four or six ewes. For mRNA analyses, cells were cultured in flasks in medium 199 plus PSF either alone or with PMA or IFN $\alpha$ for $48 \mathrm{~h}$, and then harvested with $0.5 \mathrm{ml} 0.1 \%$ $(\mathrm{w} / \mathrm{v})$ trypsin $0.02 \%(\mathrm{w} / \mathrm{v})$ versene (Flow Laboratories).

\section{Enzyme assays}

MMP-1 (interstitial collagenase) activity was measured by the diffuse fibril method of Cawston and Barrett (1979), using ${ }^{14} \mathrm{C}$-acetylated type- 1 collagen prepared by salt extraction from guinea-pig skin and incubation at $37^{\circ} \mathrm{C}$ for $20 \mathrm{~h}$. Gelatinolytic activity (predominantly MMP-2; gelatinase $\mathrm{A}$ ) was measured using heat-denatured ${ }^{14} \mathrm{C}$-acetylated type- $\mathrm{I}$ collagen incubated at $37^{\circ} \mathrm{C}$ for $4 \mathrm{~h}$ according to the method of Harris and Krane (1972). MMP-3 (stromelysin 1) activity was measured using reduced ${ }^{3} \mathrm{H}$-carboxymethylated transferrin (CmTf), as described by Okada et al. (1986). All samples were assayed in duplicate for enzyme activity in the activated form following preincubation of the samples with $1.5 \mathrm{mmol}$ (4-aminophenyl)mercuric acetate (APMA) $1^{-1}$. In each case, I $U$ enzyme activity was defined as that amount of enzyme capable of degrading $I \mu \mathrm{g}$ substrate $\min ^{-1}$ at $37^{\circ} \mathrm{C}$. Sensitivities of the assays are $0.05 \mathrm{U} \mathrm{ml}^{-1}$ for MMP-I and $0.02 \mathrm{U} \mathrm{ml}^{-1}$ for MMP-3. The mean intra-assay coefficient of variation for the MMP-1 assay was $3.7 \%$ and $5.4 \%$ for the MMP-3 assay. Aliquots of a single sample were included in every assay, and the interassay variability was calculated as $70.7 \%$ for the MMP-1 assay and $35.8 \%$ for the MMP-3 assay. All samples from a single experiment were assayed in single assays and data were expressed as percentages of control values (no added treatments: $100 \%$ ).

\section{Zymography}

MMP- $1,-2$ and -3 activity in the culture medium was also analysed by zymography. Media samples were subjected to SDS-PAGE on a $10 \%$ acrylamide slab gel containing $1 \mathrm{mg}$ gelatin or casein $\mathrm{ml}^{-1}$ (Sigma Chemical Co.) under nonreducing conditions. After washing the gels in a buffer containing $50 \mathrm{mmol}$ Tris $-\mathrm{HCl} \mathrm{l}^{-1}, 5 \mathrm{mmol} \mathrm{ZnCl}_{2} \mathrm{I}^{-1}, 0.02 \%(\mathrm{w} / \mathrm{v})$ $\mathrm{NaN}_{3}(\mathrm{pH} 7.5)$ and $1 \%$ Triton $\mathrm{X}-100$, the gels were incubated in the same buffer without Triton $X-100$ at $37^{\circ} \mathrm{C}$ for $20 \mathrm{~h}$ and stained with Coomassie Brilliant Blue G250. Enzyme activities were visualized by negative staining. Individual 
MMPs were identified using molecular weight standards run on the same gels, with laboratory standards for proMMP-2 activity (conditioned medium from a culture of human synovial cells) or with purified human proMMP-3 and proMMP-1 (on the casein gels). All MMP activity was inhibited by including $10 \mathrm{mmol}$ EDTA $\mathrm{l}^{-1}$ in the incubation buffer.

\section{Probes}

Human proMMP-I cDNA ( $1.6 \mathrm{~kb})$ was isolated from a human colon cancer Lo-Vo cell cDNA library. Sequencing indicated that this cDNA is identical to human fibroblast proMMP- 1 cDNA except for two bases (B. $X_{i e}$ and $H$. Nagase, unpublished). The probe was labelled with $\left[\alpha^{32} \mathrm{P}\right] \mathrm{CTP}$ (Bresatec, Adelaide) to a specific activity of $1-3 \times 10^{9}$ c.p.m. $\mu \mathrm{g}^{-1}$. The rat glyceraldehyde 3-phosphate dehydrogenase (GAPDH) cRNA probe used was complementary to nucleotides 96-660 of the cDNA clone (Tso ef al., 1985) and was labelled with ${ }^{32}$ P]UTP to a specific activity of $10^{8}$ c.p.m. $\mu \mathrm{g}^{-1}$.

\section{Northern analyses}

Total RNA was isolated from harvested cells by a singlestep extraction with guanidinium isothiocyanate, phenol and chloroform (Chomczynski and Sacchi, 1987). For northern blotting, $20 \mu \mathrm{g}$ total RNA was denatured in 1 mol glyoxal $1^{-1}$ containing $50 \%$ dimethyl sulfoxide, and subjected to electrophoresis in a $1.2 \%$ agarose gel, and passively transferred to Hybond (Amersham Australia, Melbourne) nylon membranes by capillary blotting. An RNA ladder (Bethesda Research Laboratories, Bethesda, MD) was used to determine the size of the bands. The nylon membrane was baked at $80^{\circ} \mathrm{C}$ for $2 \mathrm{~h}$, crosslinked with uv for $10 \mathrm{~min}$ and prehybridized for $4 \mathrm{~h}$ at $42^{\circ} \mathrm{C}$ in the following hybridization buffer: $50 \%$ formamide, $1 \times$ Denhardt's solution $(50 \times 0.02 \%$ each of Ficoll, polyvinylpyrrolidone and $\mathrm{BSA}), 5 \times \mathrm{SSPE}\left(0.75 \mathrm{~mol} \mathrm{NaCl} \mathrm{l^{-1 }}\right.$ $50 \mathrm{mmol} \mathrm{NaH}_{2} \mathrm{PO}_{4} \cdot 2 \mathrm{H}_{2} \mathrm{O} \mathrm{I}^{-1}$, and $5 \mathrm{mmol}$ EDTA I ${ }^{-1}$, $\mathrm{pH}$ 7.4) and $100 \mathrm{mg}^{2}$ pre-boiled herring spermatozoa DNA ml ${ }^{-1}$ The blot was hybridized with the ${ }^{32} \mathrm{P}$-labelled proMMP-1 probe $\left(2 \times 10^{6}\right.$ c.p.m. ml $\left.{ }^{-1}\right)$ for $17 \mathrm{~h}$ at $42^{\circ} \mathrm{C}$, and washed in $2 \times$ SSC ( $\mathrm{I} \times \mathrm{SSC}$ is $0.15 \mathrm{~mol}$ sodium chloride $\mathrm{l}^{-1}$ and $0.15 \mathrm{~mol}$ sodium citrate $\mathrm{l}^{-1}, \mathrm{pH} 7.4$ ) containing $0.1 \% \mathrm{SDS}$ at room temperature and then in $2 \times \mathrm{SSC}$ and $0.1 \% \mathrm{SDS}$ at $42^{\circ} \mathrm{C}$. For the GAPDH probe $\left(2 \times 10^{6}\right.$ c.p.m. $\left.\mathrm{ml}^{-1}\right)$, pre-hybridization was for $4 \mathrm{~h}$ at $42^{\circ} \mathrm{C}$ in a solution containing $50 \%$ formamide, $5 \times$ SSPE, $0.15 \mathrm{~mol}$ Tris-HCl $1^{-1}(\mathrm{pH} 8), 1 \%$ SDS and $125 \mathrm{iu}$ heparin $\mathrm{ml}^{-1}$. Hybridization was for $17 \mathrm{~h}$ in the same solution at $60^{\circ} \mathrm{C}$ and the blot was washed to its highest stringency with $0.2 \times \mathrm{SSC}$ and $0.1 \%$ SDS at $70^{\circ} \mathrm{C}$. Autoradiography was performed with Fuji $\mathrm{RX}$ film and an intensifying screen at $-70^{\circ} \mathrm{C}$ for 11 days and $22 \mathrm{~h}$ (proMMP- 1 and GAPDH, respectively) and densitometric analysis was performed using an Olympus Cue 2 image analyser.

\section{Statistical analyses}

The absolute concentration of each enzyme measured by enzyme assays varied between batches of cells derived from different animals; for this reason, data were normalized within animals and expressed as percentages of enzyme activities in control wells (no treatment: $100 \%$ ). Normal distribution of data was confirmed using Bartlett's test. Data from enzyme assays were analysed by one-way analysis of variance and Duncan's multiple range $F$ test. Differences were considered significant when $P<0.05$.

\section{Results}

\section{Modulation of MMP-1, MMP-2 and MMP-3 production by IFN $\tau$ and IFNa}

MMP-1, -2 and -3 activities were observed in conditioned medium from ovine endometrial cells; much of the enzyme present was in the latent form and required activation in vitro with APMA, as demonstrated by Salamonsen et al. (1991b, 1993; data not shown). Mean MMP activities $\left(\mathrm{U} \mathrm{ml}^{-1} \pm \mathrm{SEM}\right.$, $n=4$ ewes) following activation were: $0.80 \pm 0.52$ for MMP-I; $1.3 \pm 0.51$ for MMP-2; and $0.80 \pm 0.52$ for MMP-3. PMA significantly increased the activity of MMP-1 and $-3(P<0.05)$ but not that of MMP-2, confirming the potential of the cells to respond to a known stimulus. Both IFN $\tau$ and IFN $\alpha$ attenuated the production of MMP-1 and MMP-3 but not of MMP-2 (Fig. 1). The inhibitory effect was greatest on MMP-1, with activities reduced below the level of detection in all cultures by both IFN $\tau$ and IFN $\alpha$. Inhibition of MMP-3 activity was only partial (mean inhibition $47 \%$ of control) using the same treatment doses.

\section{Effect of indomethacin treatment on MMP production}

Addition of exogenous prostaglandins $\left(\mathrm{PGE}_{2}\right.$ and $\left.\mathrm{PGF}_{2 \alpha}\right)$ to the cell cultures had no effect on the activity of MMP-1 or MMP-3 in the culture medium (Fig. 2), whereas the activity of both were significantly decreased $(P<0.05)$ by treating the cells with indomethacin. These activities were partially restored by $\mathrm{PGE}_{2}$ or $\mathrm{PGF}_{2 a}$ added separately or together to the cultures. These data were confirmed by casein zymography (shown in part in Fig. 3a), which detected both proMMP-1 (52 kDA), proMMP-3 $(57 \mathrm{kDa})$ and the active forms of these enzymes. No effects of either indomethacin or prostaglandins on either proMMP-2 $(72 \mathrm{kDa})$ or active MMP-2 $(67 \mathrm{kDa})$ production were demonstrated using gelatin zymography (Fig. $3 \mathrm{~b}$ ).

MMP production following treatment of cells with a combination of interferons and prostaglandins

Mean MMP-1 and MMP-3 activities were significantly decreased by IFNa, as before. However, enzyme activity was not restored by adding $\mathrm{PGE}_{2}$ or $\mathrm{PGF}_{2 \alpha}$ to the cell cultures, either separately or in combination (Figs 3a and 4), unlike the restoration seen following indomethacin treatment. ProMMP-2 activity detected by zymography was not altered by treatment with IFNa (Fig. 3b). 

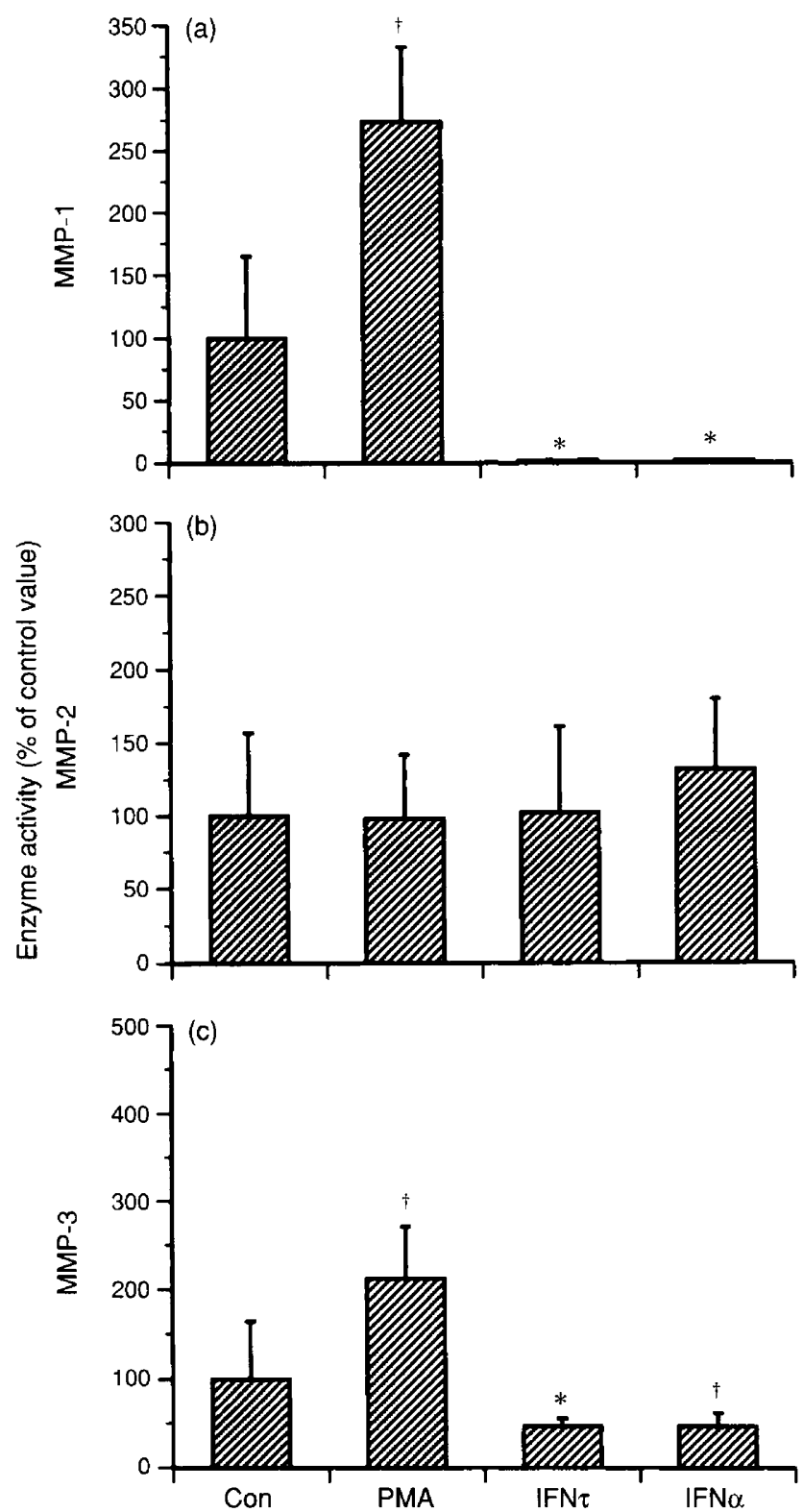

Fig. 1. Activities of (a) matrix metalloproteinase-I (MMP-I), (b) MMP-2 and (c) MMP-3 in medium from ovine endometrial cells cultured without treatments (Con) or with $40 \mathrm{nmol}$ phorbol myristate acetate (PMA) $1^{-1}, 30 \mathrm{ng}$ trophoblast interferon (IFN $\left.\tau\right) \mathrm{ml}^{-1}$ or $50 \mathrm{U}$ human recombinant interferon (IFNa) $\mathrm{ml}^{-1}$. Activities were measured following the activation of latent enzyme with (4-aminophenyl)mercuric acetate. All cultures were in triplicate and assays were performed in duplicate. Data from four ewes are expressed as mean percentage of control value \pm SEM. ${ }^{*} P<0.05$ compared with control; ${ }^{\dagger} 0.06>P>0.05$.

Effect of combined treatments with PMA, indomethacin and interferons

PMA significantly stimulated MMP- $1(P<0.05)$ production by ovine endometrial cells (Fig. 5). MMP-3 production was also increased, but not significantly owing to variability among animals. This stimulation was not diminished when PMA was administered in combination with either indomethacin, IFN $\alpha$ or
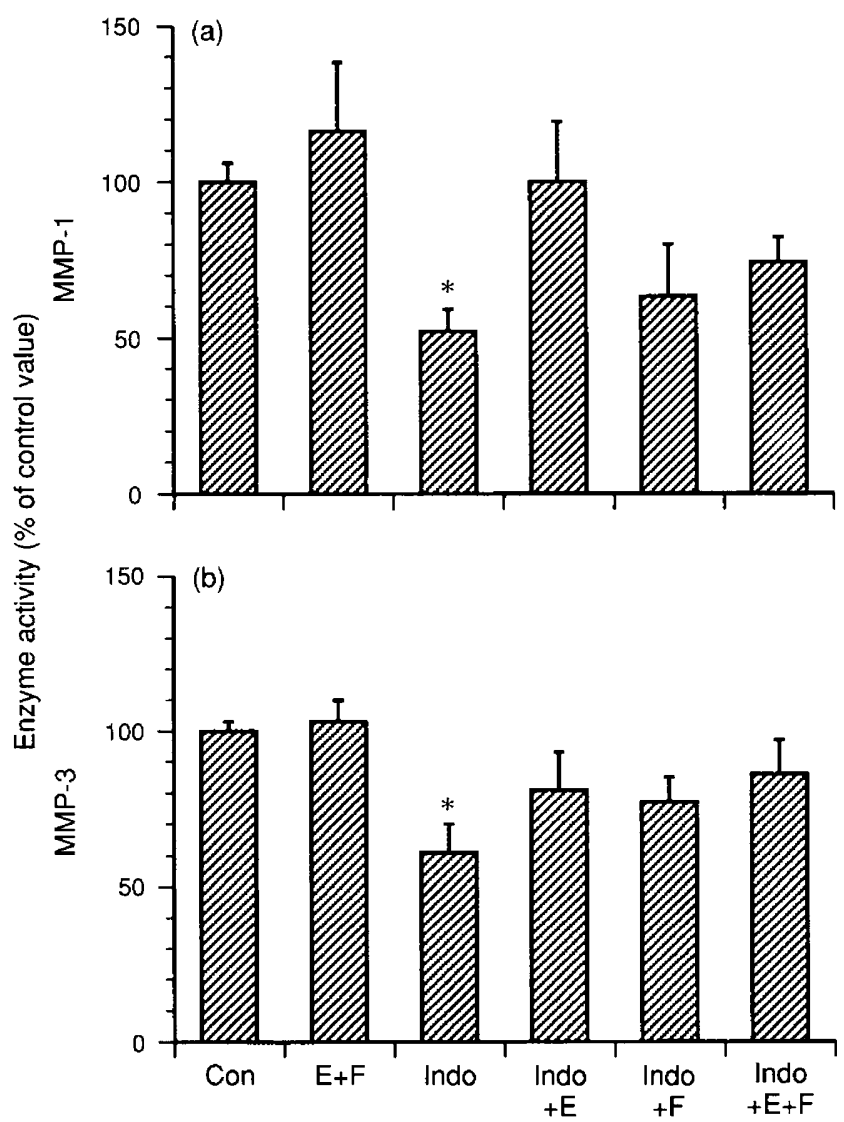

Fig. 2. Activities of (a) matrix metalloproteinase- 1 (MMP-1) and (b) MMP-3 in medium from ovine endometrial cells cultured alone (Con), with added $10 \mu \mathrm{mol}$ prostaglandin $E_{2}(E) l^{-1}$ and $10 \mu \mathrm{mol}$ prostaglandin $F_{2 \alpha}$ (F) $1^{-1}, 12 \mu \mathrm{mol}$ indomethacin (Indo) $1^{-1}$, and indomethacin with added $\mathrm{E}, \mathrm{F}$ or $\mathrm{E}$ plus $\mathrm{F}$. Activities were measured following the activation of latent enzyme with (4aminophenyl)mercuric acetate. Data are expressed as mean percentage of control value $\pm \operatorname{sEM}(n=6$ ewes). $* p<0.05$ compared with control.

$\mathrm{PGE}_{2}$ plus $\mathrm{PGF}_{2 \alpha}$ (Figs 5 and 3a). PMA had little effect on the production of proMMP-2, as detected by zymography (Fig. 3b).

Effect of PMA and interferons on the steady-state concentrations of $m R N A$ encoding proMMP-1 in ovine endometrial cells

Northern analysis of total RNA derived from ovine endometrial cells and hybridized with the ${ }^{32} \mathrm{P}$-labelled $\mathrm{cDNA}$ probe for human proMMP-1 detected an mRNA of $2.2 \mathrm{~kb}$ (using the standard RNA ladder). Analysis of mRNA from either untreated cells or those subjected to PMA or IFN $\alpha$ treatment demonstrated a marked increase in the abundance of mRNA encoding proMMP-1 following PMA treatment. The abundance of mRNA encoding proMMP-I was decreased to concentrations that could not be measured by densitometry following incubation with doses of IFN $\alpha$ that resulted in lowered MMP-1 activity in the culture medium (Fig. 6). A second, much smaller band of hybridization could be seen at $1.8 \mathrm{~kb}$, the size of the mRNA encoding proMMP-3, and presumably is a result of crosshybridization of the probe. This 
(a)

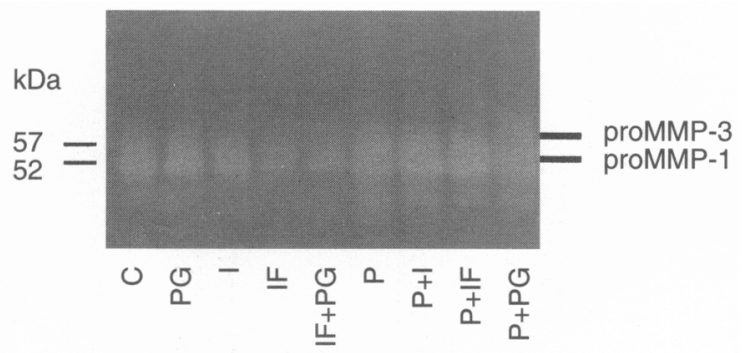

(b)

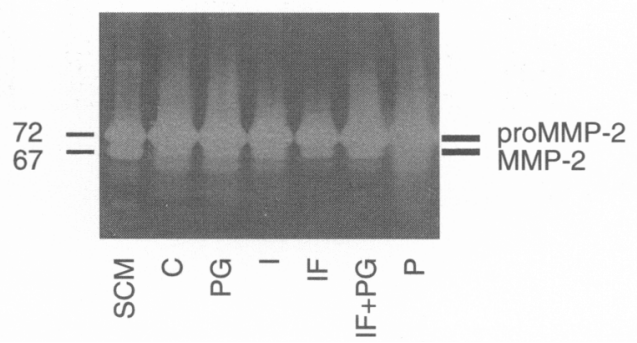

Fig. 3. (a) Casein and (b) gelatin zymography of culture medium from ovine endometrial cells, untreated $(\mathrm{C})$ or treated in vitro with prostaglandin $\mathrm{E}_{2}$ and prostaglandin $\mathrm{F}_{2 a}(\mathrm{PG})$, indomethacin (I), interferon (IF), or phorbol myristate acetate $(\mathrm{P})$ alone or in combination. Human synovial cell culture medium ( $\mathrm{SCM}$ ) is used as a standard for matrix metalloproteinase-2 (MMP-2). Latent matrix metalloproteinases- 1 and -3 (proMMP-1 and proMMP-3) were identified by comparison with purified human standards.

result is similar to that obtained for proMMP-1 with the treatments in vitro (Fig. 1). Hybridization of the same northern blot with the oligonucleotide probe for GAPDH demonstrated equivalent loading of total RNA in each lane.

\section{Discussion}

IFN $\tau$, the major product of the sheep blastocyst at the time of implantation, has an inhibitory effect in vitro on the release of both proMMP-1 and proMMP-3 by ovine endometrial cells, but does not alter the production of proMMP-2. Northern analysis demonstrated that IFN $\alpha$ reduced the steady-state concentration of mRNA encoding proMMP-1 in the cell cultures in contrast to the stimulation seen with PMA. The actions of interferons on these MMPs were not mediated by attenuating the production of endometrial prostaglandins (Salamonsen et al., 1988, 1989), as addition of both $\mathrm{PGE}_{2}$ and $\mathrm{PGF}_{2 a}$ to the cell cultures in the presence of human IFNa did not restore MMP production, even in part. This is in contrast to the situation in which indomethacin (an inhibitor of prostaglandin synthase and hence of prostaglandin synthesis) similarly inhibited MMP production in an action reversed by exogenous prostaglandins. The stimulation of both proMMP-1 and proMMP-3 production by PMA (an agonist of protein kinase $C$ and hence a stimulator of prostaglandin release) in this study confirms our previous findings (Salamonsen et al., 1991b, 1993). Since none of the other regulators examined (interferons, indomethacin or prostaglandins) modified MMP production in the presence of PMA, it appears that while proMMP-1 and proMMP-3 production by ovine endometrial cells can be regulated by IFN $\tau$ and IFN $\alpha$, by prostaglandins and
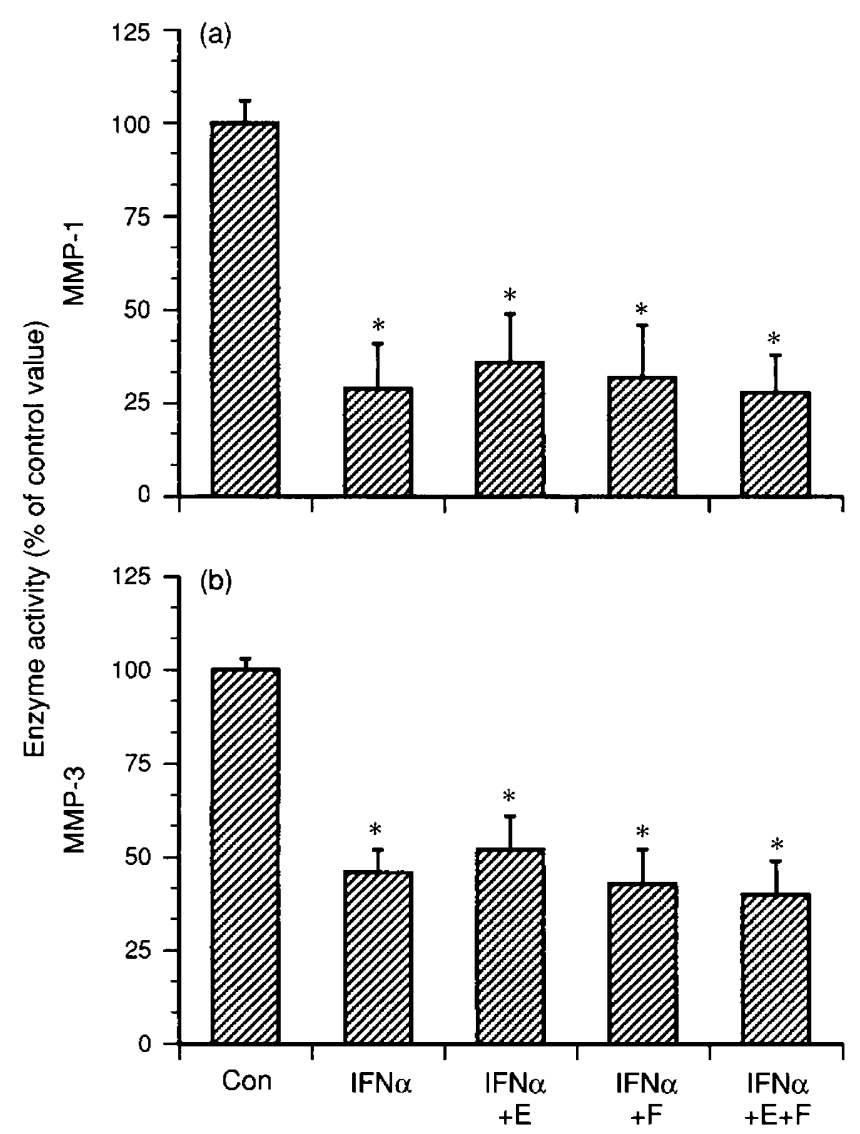

Fig. 4. Activities of (a) matrix metalloproteinase-1 (MMP-1) and (b) MMP-3 in medium from ovine endometrial cells cultured alone (Con), or with human recombinant interferon (IFN $\alpha$ ) alone or in combination with $10 \mu \mathrm{mol}$ prostaglandin $E_{2}$ (E) $\mathrm{l}^{-1}, 10 \mu \mathrm{mol}$ prostaglandin $\mathrm{F}_{2 a}(\mathrm{~F}) \mathrm{l}^{-1}$ or $\mathrm{E}$ plus $\mathrm{F}$. Activities were measured following the activation of latent enzyme with (4-aminophenyl)mercuric acetate. Data are expressed as mean percentage of control $\pm \operatorname{SEM}(n=6$ ewes). ${ }^{*} P<0.05$ compared with control.

by PMA, the mechanisms of action of these regulatory molecules are different.

$\alpha$-Interferons have been implicated in the regulation of MMP production in a variety of cells. MMP- 1 is stimulated by IFNa in cultured human dermal fibroblasts (Duncan and Berman, 1989), in keloidal fibroblasts (Berman and Duncan, 1989) and in Ewing sarcoma cells (Siegal et al., 1982). In addition, the invasive potential of human melanoma can be modulated in vitro by IFN $\alpha$ (Hujanen and TurpeenniemiHujanen, 1991), suggesting that it inhibits MMP synthesis or action. Whether trophoblast interferons have properties uniquely different from IFN $\alpha$ has not been fully established but in most test systems in vitro their biological activities are essentially indistinguishable; it is therefore likely that IFN $\tau$ acts as a classical type- 1 interferon (Roberts et al., 1992) via IFN $\alpha / \beta$ receptors. In the ovine endometrium, ${ }^{125}$ I-labelled IFN $\tau$ binds to the epithelium (Godkin et al., 1984), although binding to stromal cells was not precluded. It is primarily the stromal rather than the epithelial cells that are the endometrial source of MMP in the sheep (Salamonsen et al., 1993, in press), and it is impossible in the present studies of mixed cells to define whether the action of IFN $\tau$ on stromal-cell MMP production is 

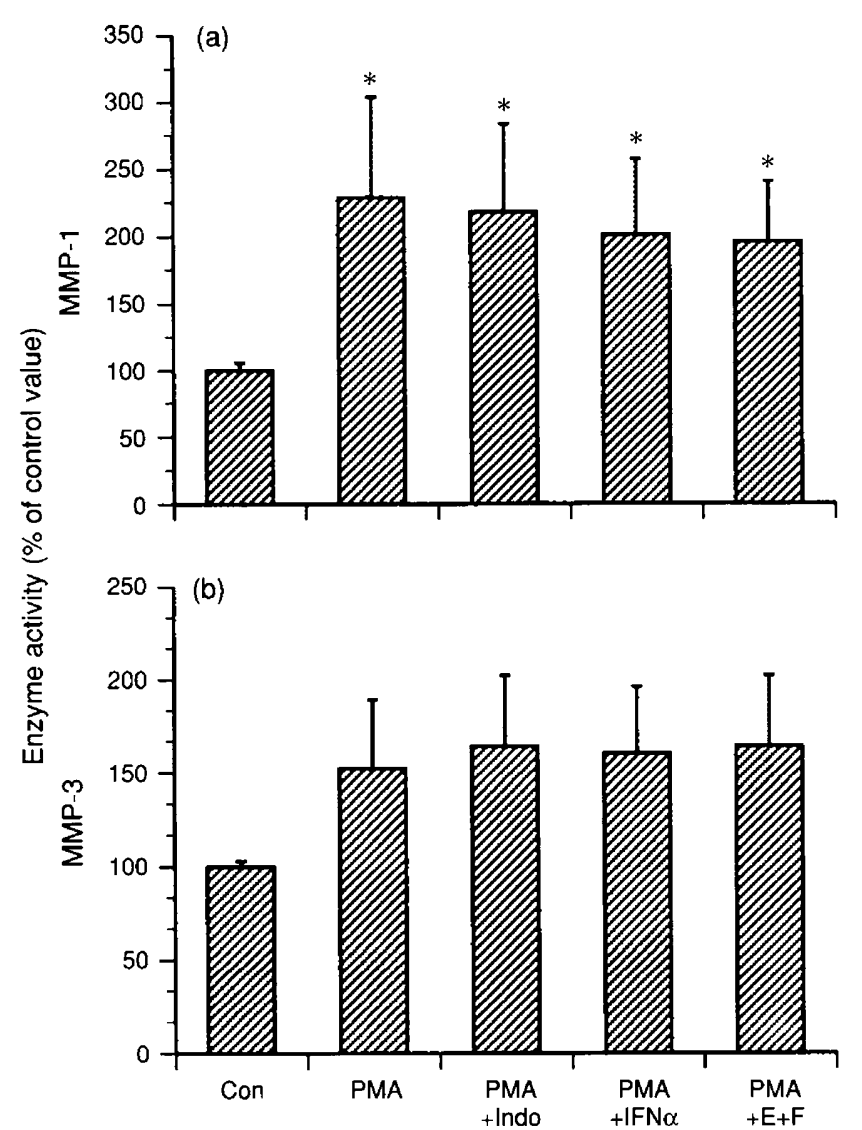

Fig. 5. Activities of (a) matrix metalloproteinase-1 (MMP-1) and (b) MMP-3 in medium from ovine endometrial cells cultured alone (Con), with added phorbol myristate acetate (PMA) alone or in combination with indomethacin (Indo), human recombinant interferon (IFN $\alpha$ ) or prostaglandin $\mathrm{E}_{2}$ plus prostaglandin $\mathrm{F}_{2 a}(\mathrm{E}+\mathrm{F})$. Activities were measured following the activation of latent enzyme with (4-aminophenyl)mercuric acetate. Data represent combined data from six ewes and are expressed as mean percentage of control value \pm SEM ( $n=6$ ewes). ${ }^{*} P<0.05$ compared with control values.

direct or mediated via interactions with epithelial cells. Furthermore, it is possible that interferons from cellular sources other than the trophoblast modulate MMP production in the uterus and thus are of general importance in the remodelling of this tissue.

Stimulatory effects of $\mathrm{PGE}_{2}$ on MMP-I production have been shown in a number of experimental models (Dayer et al., 1984; Krane et al., 1985; Goshowaki et al., 1988) and in the present study prostaglandins stimulated both MMP-I and MMP-3 secretion from indomethacin-treated cells, although they had no effect on untreated cells. Ovine endometrial cells in culture under these conditions and without specific stimuli secrete both PGE and PGF $_{2 \alpha^{\prime}}$ the PGE being derived primarily from the stromal cells (Salamonsen et al., 1991a) that are also the major source of MMPs in these cell cultures (Salamonsen et al., 1993, in press). It is therefore likely that endogenously produced prostaglandins acting in an autocrine or paracrine manner are exerting their maximal effect on MMP synthesis and masking any potential actions of exogenous prostaglandins. The actions of prostaglandins in MMP regulation in a

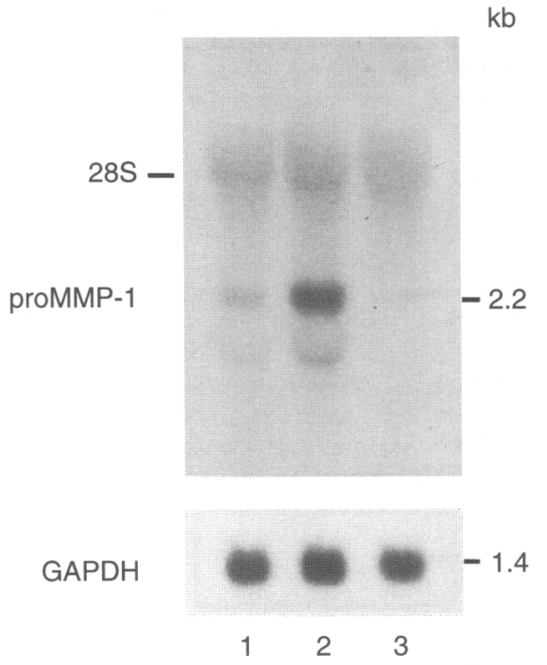

Fig. 6. Northern blot analysis of total RNA (20 $\mu \mathrm{g}$ per lane) from ovine endometrial cells hybridized with a ${ }^{32} \mathrm{P}$-labelled cDNA probe for latent matrix metalloproteinase-1 (proMMP-1) and a cRNA probe for glyceraldehyde 3-phosphate dehydrogenase (GAPDH). Lane 1: control cells (untreated); lane 2: cells treated with phorbol myristate acetate (PMA) for $48 \mathrm{~h}$; lane 3: cells treated with human recombinant interferon (IFN $\mathrm{N}$ ) for $48 \mathrm{~h}$. $\mathrm{Kb}$ values were assigned by reference to an RNA ladder run on the same gel. Autoradiography was for II days for proMMP- 1 and $22 \mathrm{~h}$ for GAPDH with Fuji RX film.

range of situations involve cAMP-dependent pathways (Case et al., 1990; Corcoran et al., 1992). Although indomethacin inhibited prostaglandin synthesis in rabbit uterine cervical fibroblasts, it did not alter MMP-1 production that had been enhanced by interleukin 1 , which, like PMA, is dependent on protein kinase C (Goshowaki et al., 1988). These studies are consistent with the findings reported here.

Thus, IFN $\tau$ acts either directly or indirectly to ensure local inhibition of proMMP-1 and proMMP-3 production. Whether the action of IFN $\tau$ on stromal-cell MMP production is direct or mediated via interactions with epithelial cells is not defined by these studies in mixed cells. Such paracrine interactions between the trophoblast, endometrial epithelium or endometrial stroma could act to limit invasion of the stroma by the trophoblast and to modulate remodelling within the endometrium. Although trophoblast cells of species such as humans are highly invasive, the use of a trophoblast protein to restrain such invasiveness may be a special adaptation in ruminants. Further studies are in progress to establish the sites of production of MMP around implantation sites, and their spatial and temporal relationships with trophoblast development and IFN $\tau$ production.

The authors thank the Director of the Victorian Institute of Agriculture at Werribee for providing large animal facilities, B. Doughton for his help with sheep handling, A. Butt for excellent technical assistance, S. Pankridge for assistance with graphical work and S. Riley for critically reading the manuscript. J. D. Godkin kindly provided the purified ovine trophoblast interferon, Hoffman La Roche (Basel) provided the human recombinant interferon $\alpha$, and P. Fuller donated the probe for GAPDH. The animal experimental work was approved by Animal Ethics Committees at the Monash Medical 
Centre and at the Victorian Institute of Agriculture. This work was supported by the National Health and Medical Research Council of Australia and NIH grant AR39189.

\section{References}

Auble DT and Brinkerhoff CE (1991) The AP-I sequence is necessary but not sufficient for phorbol induction of collagenase in fibroblasts Biochemistry 30 4629-4635

Berman B and Duncan MR (1989) Short-term keloid treatment in vivo with human interferon-alpha $2 \mathrm{~B}$ results in a selective and persistent normalization of keloidal fibroblast collagen, glycosaminoglycan and collagenase production in vitro Joumal of the American Academy of Dermatology 21 694-702

Bindon BM (1971) Systematic study of preimplantation stages of pregnancy in the sheep Australian Journal of Biological Sciences 24 131-147

Birkedal-Hansen H, Moore WGI, Bodden MK, Windsor LJ, Birkedal-Hansen B, De Carlo A and Engler JA (1993) Matrix metalloproteinases: a review Critical Reviews of Oral Biology and Medicine 4 199-250

Brenner DA, O'Hara M, Angel P, Chojkier M and Karin M (1989) Prolonged activation of jun and collagenase genes by tumor necrosis factor alpha Nature 337 661-663

Case JP, Lafyatis R, Kumkumian GK, Remmers EF and Wilder RL (1990) IL-1 regulation of transin/stromelysin transcription in rheumatoid synovial fibroblasts appears to involve two antagonistic transduction pathways, an inhibitory, prostaglandin-dependent pathway mediated by cAMP and a stimulatory protein kinase C-dependent pathway Joumal of Immunology 145 $3755-3761$

Cawston TE and Barrett AJ (1979) A rapid and reproducible assay for collagenase using (1-I4C)acetylated collagen Analytical Biochemistry 99 340-345

Charpigny G, Reinaud P, Huet J-C, Guillomot M, Charlier M, Pernollet J-C and Martel J (1988) High homology between a trophoblast protein (trophoblastin) isolated from ovine embryo and $\alpha$-interferon FEBS Letters 228 12-16

Chomczynski P and Sacchi N (1987) Single-step method of RNA isolation by acid guanidinium thiocyanate-phenol-chloroform extraction Analytical Biochemistry 162 156-159

Corcoran ML, Stetler-Stevenson WG, Brown PD and Wahl LM (1992) Interleukin 4 inhibition of prostaglandin $\mathrm{E}_{2}$ synthesis blocks interstitial collagenase and 92-kDa type IV collagenase/gelatinase production by human monocytes Journal of Biological Chemistry 267 515-519

Dayer J-M, Roelki MS and Krane SM (1984) Effects of prostaglandin $E_{2}$ indomethacin, trifluoperazine and drugs affecting the cytoskeleton on collagenase production by cultured adherent rheumatoid synovial cells Biochemical Pharmacology 33 2893-2900

Duncan MR and Berman B (1989) Differential regulation of glycosaminoglycan, fibronectin and collagenase production in cultured human dermal fibroblasts by interferon-alpha, -beta and -gamma Archives of Dermatological Research 281 11-18

Francis H, Keisler DH and Roberts RM (1991) Induction of the synthesis of the pregnancy-specific protein, p70 by intramuscular injection of recombinant bovine interferon- $\alpha 11$ into non-pregnant ewes Journal of Reproduction and Fertility $93 \quad 367-374$

Godkin JD, Bazer FW, Moffatt J, Sessions F and Roberts RM (1982) Purification and properties of a major, low molecular weight protein released by the trophoblast of sheep blastocysts at Day 13-21 Journal of Reproduction and Fertility 65 141-150

Godkin JD, Bazer FW and Roberts RM (1984) Ovine trophoblast protein 1, an early secreted blastocyst protein, binds specifically to uterine endometrium and affects protein synthesis Endocrinology 114 120-130

Goshowaki H, Ito A and Mori Y (1988) Effects of prostaglandins on the production of collagenase by rabbit uterine cervical fibroblasts Prostaglandins 36 107-114

Hansen TR, Kazemi M, Keisler DH, Malathy PV, Imakawa K and Roberts RM (1989) Complex binding of the embryonic interferon, ovine trophoblast protein-1 to endometrial receptors Joumal of Interferon Research 9 215-225

Harris ED and Krane SM (1972) An endopeptidase from rheumatoid synovial tissue culture Biochimica et Biophysica Acta 258 566-576
Hujanen ES and Turpeenniemi-Hujanen T (1991) Recombinant interferon-alpha and interferon-gamma modulate the invasive potential of human melanoma in vitro International Joumal of Cancer 47 23477-23482

Imakawa K, Anthony RV, Kazemi M, Marotti KR, Polites HG and Roberts RM (1987) Interferon-like sequence of ovine trophoblast protein secreted by embryonic trophectoderm Nature $330337-379$

Jonat C, Ramsdorf HJ, Park K-K, Cato ACB, Gebel S, Ponta H and Herrlich P (1990) Antitumor promotion and antiinflammation: down-modulation of AP-1 (Fos/Jun) activity by glucocorticoid hormone Cell 62 1189-1204

Knickerbocker JJ and Niswender GD (1989) Characterization of endometrial receptors for ovine trophoblast protein-1 during the estrous cycle and early pregnancy in sheep Biology of Reproduction 40 361-369

Krane SM, Dayer J-M, Simon LS and Byrne MS (1985) Mononuclear cell conditioned medium containing mononuclear cell factor $(\mathrm{MCF})$ homologous with interleukin-I stimulated collagen and fibronectin synthesis by adherent rheumatoid synovial cells: effect of prostaglandin E2 and indomethacin Collagen and Related Research 5 99-117

Okada Y, Nagase H and Harris ED (1986) A metalloproteinase from human rheumatoid synovial fibroblasts that digests connective tissue matrix components Journal of Biological Chemistry 261 14245-14255

Roberts RM, Cross JC and Leaman DW (1992) Interferons as hormones of pregnancy Endocrine Reviews 13 432-452

Russell D, Manalo GG, Jr, Findlay JK and Salamonsen LA (1993) Binding sites for interferons on ovine and human endometrial membranes Reproduction Fertility and Development 5 219-227

Salamonsen LA, Doughton BW and Findlay JK (1984) Protein synthesis by preimplantaion sheep blastocysts. In Reproduction in Sheep, pp 115117 Eds DA Lindsay and DT Pearce. Australian Academy of Science, Canberra

Salamonsen LA, Stuchbery SJ, O'Grady CM, Godkin JD and Findlay JK (1988) Interferon mimics effects of ovine trophoblast protein- $I$ on prostaglandin and protein secretion by ovine endometrial cells in vitro Journal of Endocrinology 117 R1-R4

Salamonsen LA, Manikhot J, Healy DL and Findlay JK (1989) Ovine trophoblast protein-1 and human interferon alpha reduce prostaglandin synthesis by ovine endometrial cells Prostaglandins 38 289-306

Salamonsen LA, Cherny RA and Findlay JK (1991a) In vitro studies of the effects of interferons on endometrial metabolism Journal of Reproduction and Fertility Supplement $4127-38$

Salamonsen LA, Nagase H and Woolley DE (1991b) Production of matrix metalloproteinase 3 (stromelysin) by cultured ovine endometrial cells Joumal of Cell Science 100 381-385

Salamonsen LA, Suzuki R, Nagase H and Woolley DE (1993) Production of matrix metalloproteinase 1 (interstitial collagenase) and matrix metalloproteinase 2 (gelatinase A: $72 \mathrm{kDa}$ gelatinase) by ovine endometrial cells in vitro: different regulation and preferential expression by stromal fibroblasts Journal of Reproduction and Fertility 98 583-589

Salamonsen LA, Suzuki R, Nagase $H$ and Woolley DE Matrix metalloproteinases: a role in implantation? In The Endocrinology of Embryo-Endometrial Interactions. Eds SR Glasser, J Mulholland and A Psychoyos. Plenum Publishing Company, New York (in press)

Sharif SF, Francis H, Keisler DH and Roberts RM (1989) Correlation between the release of ovine trophoblast protein-I by the conceptus and the production of polypeptides by the maternal endometrium of ewes Journal of Reproduction and Fertility 85 471-476

Siegal GP, Thorgeirsson UP, Russo RG, Wallace DM, Liotta LA and Berger SL (1982) Interferon enhancement of the invasive capacity of Ewing sarcoma cells in vitro Proceedings of the National Academy of Sciences, USA 79 4064-4068

Stewart HJ, McCann SHE, Barker PJ, Lee KE, Lamming GE and Flint APF (1987) Interferon sequence homology and receptor binding activity of ovine trophoblast antiluteolytic protein Journal of Endocrinology 115 R13-R15

Tso JY, Sun X-H, Kao T-H, Reece KS and Wu R (1985) Isolation and characterization of rat and human glyceraldehyde 3-phosphate dehydrogenase cDNAs: genomic complexity and molecular evolution of the gene Nucleic Acids Research 13 2485-2502

Vallet JL, Bazer FW, Fliss MFV and Thatcher WW (1988) Effect of ovine conceptus secretory proteins and purified ovine trophoblast protein-1 on interoestrous interval and plasma concentrations of prostaglandin $\mathrm{F}_{2 \alpha}$ and $\mathrm{E}$ and of 13,14-dihydro-15-keto prostaglandin $F_{2 \alpha}$ in cyclic ewes Journal of Reproduction and Fertility 84 493-504 
Vallet IL, Barker PJ, Lamming GE, Skinner N and Huskisson NS (1991) A low molecular weight endometrial secretory protein which is increased by ovine trophoblast protein- $I$ is a $\beta 2$-microglobulin-like protein Journal of Endocrinology 130 R1-R4

Weitlauf HM (1988) Biology of implantation. In The Physiology of Reproduction, pp 231-262 Eds E Knobil and J Neill. Raven Press, New York

Woessner JF, Jr (1991) Matrix metalloproteinases and their inhibitors in connective tissue remodeling FASEB Journal 5 2145-2154
Wooding FBP and Morgan G (1989) Fetomaternal cell fusion at ruminant implantation. In Blastocyst Implantation, pp 117-12.3 Ed. K Yoshinaga. Adams Publishing Group, Boston

Yang-Yen H-F, Chambard J-C, Sun Y-L, Smeal T, Schmidt TJ, Drouin J and Karin M (1990) Transcriptional interference between c-jun and the glucocorticoid receptor: mutual inhibition of DNA binding due to direct protein-protein interaction Cell 62 1205-1215 